\title{
Audit Firm Rotation - Concerns And Considerations
}

Kam C. Chan, Pace University, USA

Barbara Farrell, Pace University, USA

Patricia Healy, Pace University, USA

\begin{abstract}
The Public Company Accounting Oversight Board (PCAOB) issued a concept release in 2011 which proposes a mandatory audit firm rotation. However, PCAOB indicates that there is a limited amount of empirical data and research evidence on the potential costs and benefits of such mandatory audit firm rotation. This study provides some empirical evidences related to PCAOB's concerns. Specifically, we find that the largest clients audited by Big 4 accounting firms have few material internal control weaknesses and accounting restatements. In addition, accounting restatements are often reported within four years after the beginning of accounting errors and are reported by the same auditor during the restatement period. These findings cast doubt on the benefit of mandatory audit firm rotation. We also find that the largest audit clients on average represent over $20 \%$ of the audit revenues of local offices of Big 4 accounting firms. Thus, mandatory audit firm rotations could significantly disrupt the normal operations of public accounting firms if audit clients are required to change auditors periodically.
\end{abstract}

Keywords: Mandatory Rotation; Audit Firms; PCAOB

\section{INTRODUCTION}

n July 30, 2002, the Sarbanes-Oxley Act (SOX) was signed into law and introduced legislative changes to financial practice and corporate governance regulation. It introduced stringent new rules with the stated objective: "to protect investors by improving the accuracy and reliability of corporate disclosures made pursuant to the securities laws" (SEC 2003). Although there has been criticism of SOX concerning its compliance costs, there have also been benefits of the legislation. For example, SOX allowed businesses to standardize reporting systems and improve internal control efficiency.

The SOX legislation also requires lead audit partners to rotate off an account after five consecutive fiscal years. This is considered as a compromise to mandatory audit firm rotation. Mandatory audit firm rotation is often considered as a stronger approach to improve auditor independence. Audit firm rotation represents a trade-off of two issues. On one hand, a new audit firm could provide more effective audits by allowing for a new pair of eyes auditing the financial statements. On the other hand, there would be a significant cost increase in time expended to get the new audit firm up to speed that the new client. A 2003 General Accounting Office report has the following overall conclusions on mandatory audit firm rotation:

We believe that mandatory audit firm rotation may not be the most efficient way to enhance auditor independence and audit quality, considering the costs of changing the auditor of record and the loss of auditor knowledge that is not carried forward to the new auditor. We also believe that the potential benefits of mandatory audit firm rotation are harder to predict and quantify while we are fairly certain there will be additional costs. In that respect, mandatory audit firm rotation is not a panacea that totally removes pressures on the auditor in appropriately resolving financial reporting issues that may materially affect the public companies' financial statements.

However in 2011, the Public Company Accounting Oversight Board (PCAOB) issued a concept release proposing a mandatory audit firm rotation. This issue is also under discussion in Europe. The European commission 
currently has a proposal before the European Parliament that would require mandatory audit firm rotation. As of December 2011, the initial comment deadline, the PCAOB received over 600 comment letters in response to the concept release for mandatory audit firm rotation. Most of those comments were from auditors and most advised that the PCAOB take more time to study the issue and instead propose more modest reforms. In March 2012, the PCAOB re-opened the comment period for one month. On October 18, 2012, the PCAOB held their third public meeting on auditor independence and audit firm rotation. The PCAOB Chairman, James Doty, said that the issue would not be decided by the volume of comments but by data based analysis that many have provided. However, empirical data on potential effects of mandatory audit firm rotation is limited.

The objective of this study is to provide some empirical data regarding specific questions raised in PCAOB's concept release. For example, the PCAOB considers if mandatory audit firm rotation be required for 10 years or more and if the requirement only be required for the very large firms. The PCAOB also consider if mandatory audit firm rotation provide a "fresh look" at financial statements that could reduce audit failure such as accounting restatements. Moreover, the PCAOB questions if mandatory audit firm rotation create disruptions to audit firms' operations. Mandatory audit firm rotation is a complex issue involving a trade-off of many costs and benefits. It is not the objective of this study to provide a definitive answer to the merits of mandatory audit firm rotation. Instead, we provide a contribution to this debate by providing empirical evidence to some of the issues that the PCAOB is considering.

Our empirical findings show that most of the large firms have high reporting quality with few accounting issues. We also find that most accounting restatements are reported by the same auditor during the restatement and restatement disclosure periods. The restatements are often reported just a few years from the beginning of the restatement period. However, we do find that the financial industry has a disproportion share of accounting restatements. An analysis of major client concentration among Big 4 show that client concentration is high in some geographical locations. This suggests that mandatory audit firm rotation could be very disruptive to audit firm operations.

The rest of this paper is organized as follows. Section 2 provides a summary of related literature and Section 3 presents our findings. Concluding remarks are presented in Section 4.

\section{RELATED LITERATURE}

The need for audit firm rotation focuses on the question of auditor independence. Simply defined, auditor independence is a state of mind that allows the auditor to perform an audit without being affected by influences that can compromise professional judgment, allowing the auditor to act with integrity, exercise objectivity, and professional skepticism. The Principles of Professional conduct of the AICPA Professional Ethics code, Article IV requires objectivity and independence. Recently, the SEC has imposed restrictions on the on the kinds of non-audit services a firm may provide an audit client in an effort to enhance auditor independence.

Although independence is clearly defined in the Principles of Professional conduct, audit failures have occurred due to lack of independence. In the case of ENRON, it was argued that a conflict of interest on the part of Arthur Andersen made it impossible for the auditors to recommend a course of action (from the consultants) and criticize that course of action (from the auditors). These types of problems led to the restrictions on non-audit services specified by SOX in 2002. Accounting firms cannot provide non-audit services such as internal auditing and information system design to auditing clients.

There are many prior studies on the costs and benefits associated with auditor tenure with client. For example, Lim and Tan (2010) examine the relationship between auditor tenure and audit quality. The auditors define audit quality as the amount of discretionary accruals and find that audit quality is enhanced by extending auditor tenure since auditors develop stronger expertise in the clients' businesses. However, the dependence on the audit fees of the clients negatively affects audit quality. The findings in Lim and Tan (2010) highlight the trade-off of costs and benefits of auditor tenure. But as suggested by the PCAOB's concept release, there is very limited research on the costs and benefits of mandatory firm rotation since prior studies are based on samples with voluntary audit firm changes. 
There are two recent studies that provide evidence related to mandatory changes in audit firms. RuizBarbadillo et al. (2009) examine the effect of mandatory audit firm rotation on the probability of auditors issuing going-concern opinions in Spain from 1985 to 1995 when mandatory audit firm rotation was required. The authors suggest that mandatory audit firm rotation could decrease economic incentive of auditors resulting in higher probability of going-concern opinion issuance. However, the findings do not suggest a significant relationship between mandatory audit firm rotation and probability of going-concern issuance. The authors conclude that their findings do not provide empirical evidence suggesting that mandatory audit firm rotation would reduce economic dependence of the audit firms on their clients. Tanyi et al. (2010) examine changes in audit report lag after involuntary audit firm changes for ex-Anderson clients in 2002. Audit lag is defined as the number of days between the fiscal year-end and the date of audit report. Tanyi et al. (2010) find significant increases in audit report lag in the year of the audit firm changes but the effect seems to be insignificant in the second year after the changes. Thus, mandatory audit firm rotation can cause decrease in the timeliness of company filings even though the effects could be temporary. Although Whalen and Cheffers (2012) do not provide direct evidence related to mandatory audit firm rotation, the authors examine the annual restatements occurred on or after January 1, 2006 by Russell 1000 companies. They find that $64 \%$ of restatements were found while the predecessor auditor was still on the engagement and only $7.5 \%$ of restatements resulted from a new auditor performing the audit of the financial statements. These findings cast doubt on the argument that audit firm tenure would affect auditor independence negatively.

\section{SAMPLE AND EMPIRICAL FINDINGS}

The sample firms in our analysis are the 100 firms with the largest market capitalization based in fiscal year 2011. We extract our data using the audit fees file in Audit Analytics database. We focus on the largest 100 firms since PCAOB suggests that the initial consideration of mandatory audit firm rotation may be just for the very largest firms in the financial markets. The total market capitalization of our sample firms represents about $50 \%$ of the total capitalization of all firms in the Audit Analytics database. Therefore, these 100 largest firms are of significant economic importance in the financial markets. We use the fiscal year 2011 as our sampling period since financial data for 2011 are completely available by the end of 2012. Table 1 provides the sample distributions of these 100 firms. Panel A of Table 1 summarizes the firm size and fees paid to public accounting firms. The average market capitalization of these firms is $\$ 87.16$ billion. The average audit and non-audit fees of these firms are $\$ 19.38$ million and $\$ 6.29$ million, respectively. Thus, the average audit fee is about $77.47 \%$ of total fees that these firms paid to their public accounting firms. Panel B show that PricewaterhouseCoopers has the most clients and Panel C shows that these 100 firms are from a large variety of industries.

Table 1: Summary Statistics of Sample Firms (Sample size $=100$ firms)

\begin{tabular}{|c|c|c|}
\hline \multicolumn{3}{|l|}{ Panel A: Sample Firm Size and Fees } \\
\hline & Mean (in 000's) & Median (in 000's) \\
\hline Market capitalization & $\$ 87,169,437$ & $\$ 57,030,392$ \\
\hline Revenues & $58,817,472$ & $37,393,000$ \\
\hline Earnings & $5,775,174$ & $3,269,000$ \\
\hline Audit fees & 19,387 & 14,000 \\
\hline Non-audit fees & 6,295 & 3,382 \\
\hline Total fees & 25,682 & 18,641 \\
\hline Audit fees as a percentage of total fees & $77.47 \%$ & $78.60 \%$ \\
\hline \multicolumn{3}{|l|}{ Panel B: Sample Firm Distribution by Public Accounting Firms } \\
\hline \multicolumn{3}{|c|}{ Number of Firms } \\
\hline PricewaterhouseCoopers & 34 & \\
\hline Ernst \& Young & 26 & \\
\hline Deloitte \& Touche & 25 & \\
\hline KPMG & 15 & \\
\hline \multicolumn{3}{|l|}{ Panel C: Sample Firm Distribution by Industries } \\
\hline & Number of Firms & \\
\hline Mining & 7 & \\
\hline Manufacturing & 45 & \\
\hline Transportation, Communications, Electric, Gas, and Sanitary Services & 14 & \\
\hline Retail Trade & 10 & \\
\hline Finance, Insurance, and Real Estate & 16 & \\
\hline Services & 8 & \\
\hline
\end{tabular}

Copyright by author(s); CC-BY 
Table 2 provides the incidences of firms with reported material internal control weaknesses under Section 404 of Sarbanes-Oxley. Panel A of Table 2 show that only five firms have reported material internal weaknesses since the fiscal years ending or after November 15, 2004, which is the initial Section 404 compliance data for accelerated filers. Except for American International Group and Mosaic, the other firms only had one material internal control weakness each. Chan, Farrell, and Lee (2008) shows that there is a significant relationship between material internal control weakness and earnings management. The findings of just a few material internal control weaknesses among the sample firms suggest that these firms have good reporting quality. Chan, Lee, and Seow (2008) reports that some management and auditors failed to identify material internal control weaknesses in their initial Section 404 reports. As a result, these management and auditors had to restate their Section 404 opinions in the subsequent periods. Panel B of Table 2 shows that there are only four cases of restatement of Section 404 opinion among the sample firms. Consistent with the findings in Chan, Lee, and Seow (2008), these firms only had relatively minor internal control problems since the discovered number of material internal control weakness is one in all four cases. Overall, the findings in Panel A suggest that there were very few reporting problems among large firms as indicated by the small number of material internal weaknesses. Thus, the benefits of requiring large firms to have mandatory audit firm rotation could be limited.

Table 2: Firms with Section 404 Material Internal Control Weaknesses

\begin{tabular}{|c|c|c|c|}
\hline \multicolumn{4}{|c|}{ Panel A: Original Section 404 Ineffective Internal Control Opinion } \\
\hline Company & Year Ended Date & $\begin{array}{l}\text { \# of Material Internal } \\
\text { Control Weaknesses }\end{array}$ & \\
\hline American International Group & $12 / 31 / 2004$ & 5 & \\
\hline American International Group & $12 / 31 / 2005$ & 3 & \\
\hline American International Group & $12 / 31 / 2006$ & 1 & \\
\hline American International Group & $12 / 31 / 2007$ & 1 & \\
\hline General Electric & $12 / 31 / 2006$ & 1 & \\
\hline Monsanto & $8 / 31 / 2011$ & 1 & \\
\hline Mosaic & $5 / 31 / 2006$ & 3 & \\
\hline Mosaic & $5 / 31 / 2007$ & 1 & \\
\hline General Motors & $12 / 31 / 2009$ & 1 & \\
\hline \multicolumn{4}{|c|}{ Panel B: Restated Section 404 Ineffective Internal Control Opinion } \\
\hline Company & Year Ended Date & Restated Opinion Date & $\begin{array}{c}\text { \# of Material Internal } \\
\text { Control Weaknesses }\end{array}$ \\
\hline Ford Motor & $12 / 31 / 2005$ & $11 / 14 / 2006$ & 1 \\
\hline General Electric & $12 / 31 / 2004$ & $5 / 5 / 2005$ & 1 \\
\hline General Electric & $12 / 31 / 2005$ & $1 / 19 / 2007$ & 1 \\
\hline Monsanto & $8 / 31 / 2010$ & $11 / 14 / 2011$ & 1 \\
\hline
\end{tabular}

Table 3 summarizes the accounting restatements of the sample firms since 2002. As shown in Panel A of Table 3, about two-thirds of the sample firms had no accounting restatements. There are 23 firms reporting one accounting restatements and eight firms with two accounting restatements. Only two firms had three accounting restatements since 2002. Panel B shows that the financial industry had the most accounting restatements probably due to the complex operating environment of the financial industry. Panel $\mathrm{C}$ also shows that 36 of the 45 accounting restatements have negative effects on financial statement numbers such as lower earnings and equity. But interestingly, the average accounting restatement period is about 1,151 days whereas the average period between the beginning of the restatement period and disclosure period is about 1,312 days. This suggests that, on average, accounting restatements was reported within four years after the beginning of the accounting error occurrence. This average period is a lot shorter than the 10 years of mandatory audit firm rotation considered by PCAOB. Thus, a 10year mandatory audit firm rotation may not improve the timeliness of accounting restatement disclosure. Panel $\mathrm{C}$ of Table 3 also shows that 39 of the 45 accounting restatements were reported by the same auditor during the restatement period. This finding is consistent with the results reported by Whalen and Cheffers (2012) that most accounting restatements are not reported by new auditors and mandatory audit firm rotation may not be needed in order to have "fresh eyes" discovering previous accounting errors. 
Table 3: Accounting Restatements among Sample Firms

\begin{tabular}{|c|c|}
\hline \multicolumn{2}{|c|}{ Panel A: Sample Distribution by Number of 45 Accounting Restatements } \\
\hline \# of Restatement Years & \# of Firms \\
\hline 0 & 67 \\
\hline 1 & 23 \\
\hline 2 & 8 \\
\hline 3 & 2 \\
\hline \multicolumn{2}{|l|}{ Panel B: Sample Distribution by Industries } \\
\hline & \# of Restatements \\
\hline Mining & 3 \\
\hline Manufacturing & 7 \\
\hline Transportation, Communications, Electric, Gas, and Sanitary Services & 4 \\
\hline Retail Trade & 5 \\
\hline Finance, Insurance, and Real Estate & 14 \\
\hline Services & 4 \\
\hline \multicolumn{2}{|l|}{ Panel C: Summary Statistics of the 45 Accounting Restatements } \\
\hline Number of restatements with negative effects on financial statements & 36 \\
\hline Number of restatements with positive effects on financial statements & 9 \\
\hline $\begin{array}{l}\text { Average number of calendar days between the beginning and end of } \\
\text { the restatement dates }\end{array}$ & 1,151 days \\
\hline $\begin{array}{l}\text { Average number of calendar days between the beginning of the } \\
\text { restatement period and disclosure date }\end{array}$ & 1,312 days \\
\hline Maximum negative cumulative restatement to net income & $-\$ 5.193$ billion \\
\hline Maximum negative cumulative restatement to equity & $-\$ 1.352$ billion \\
\hline $\begin{array}{l}\text { Number of restatements with the same auditor in the restatement and } \\
\text { disclosure periods }\end{array}$ & 39 \\
\hline
\end{tabular}

Table 4 provides data on client concentration among the Big 4 accounting firms. For each of the 100 sample firms, we compute a ratio of total audit fees of each firm in relation to the sum of total fees of the local audit firm office from all clients in that office. The data might be over or understated since so much work is done by multiple offices for major audit clients, with only one office being officially recognized as the lead office on the client. The findings in Table 4 suggest that the sample firms provide on average about $20-26 \%$ of a local audit firm's total fee revenues. Thus, mandatory audit firm changes could have a significant disruptive impact on a particular office in terms of managing its staff in the long term. This effect on audit firm is considered as one of the main negative effects of mandatory audit firm rotation (Bowsher et al., 2012). Dangherty et al. (2012) provide survey findings that audit firm partners would have to switch to other industry specializations in order to avoid relocation to other offices under the current mandatory audit partner requirements. Mandatory audit firm rotation would affect even more audit firm employees. Although this would not be a reason to justify not requiring audit firm rotation, this is an important factor that PCAOB should consider in reaching it decisions on mandatory audit firm rotation.

Table 4: Client Concentration in Local Markets

\begin{tabular}{lccc}
\hline & \# of Firms & Mean $^{\mathbf{a}}$ & Median $^{\mathbf{a}}$ \\
\hline Big 4 & 80 & 0.2278 & 0.1634 \\
PricewaterhouseCoopers & 24 & 0.2355 & 0.2043 \\
Ernst \& Young & 24 & 0.2000 & 0.1449 \\
Deloitte \& Touche & 19 & 0.2614 & 0.2037 \\
KPMG & 13 & 0.2157 & 0.1552 \\
\hline
\end{tabular}

a: A ratio of total audit fees of each client in relation to the sum of total fees of the Big4 office from all clients in that office. The top $10 \%$ and bottom $10 \%$ of the sample firms in terms of the ratio are excluded to avoid outlier problems.

\section{CONCLUSION}

This study provides some empirical findings regarding PCAOB's proposal on mandatory audit firm rotation among large firms. We find that large firms, in general, have few material internal control weaknesses and accounting restatements. In addition, accounting restatements are often reported within four years after the beginning of accounting errors and are reported by the same auditor during the restatement period. We also find that large firms represent significant portion of some local audit firms' revenues. Thus, mandatory audit firm rotation could force many auditors to relocate to other offices or switch to other industry specialization. These findings cast 
doubts on the benefit of mandatory audit firm rotation and suggest concerns on the potential costs to the operation of audit firms. Future studies should further investigate other costs and benefits expressed by PCAOB in its 2011 concept release to provide more empirical data toward this debate.

\section{AUTHOR INFORMATION}

Kam C. Chan is a professor of accounting at Pace University. He received his Ph.D. degree from the University of South Carolina in 1991. His research interests include capital market research in auditing, financial accounting, and international accounting. He has published in top journals such as Accounting, Organizations and Society, Auditing: A Journal of Practice and Theory, and Journal of Accounting and Economics. E-mail: kchan@pace.edu (Corresponding author)

Barbara Farrell is a professor at Pace University. Dr. Farrell has extensive experience teaching in corporate classes. These classes included CMA review and computer application classes for corporations such as IBM, Readers Digest and many others. Dr. Farrell has a BBA and MBA from Pace University and an EdD from Columbia University. She is a CPA. Prior to entering education, Dr. Farrell was an auditor in both "Big 8" public accounting and in the private sector specializing in computer auditing. Dr. Farrell has published in CPA Journal, Journal of Forensic Accounting, and Auditing: A Journal of Practice and Theory. E-mail: bfarrell@ pace.edu

Patricia Healy is an associate professor of accounting and the undergraduate program chair for the accounting department at the Pace University. Professor Healy has received the Pace University Kenan Award for teaching excellence and the teacher of the year award from the Robert S. Pace accounting society. She was an auditor for PriceWaterhouseCoopers and is a CPA and a CMA. She has consulted for clients such as IBM, Corning, Kraft, and Hudson Valley Hospital Center. Professor Healy has published papers on international auditing standards, quality controls, diversity issues in business, implementing the Balanced Scorecard and governmental accounting issues. E-mail: phealy@pace.edu

\section{REFERENCES}

1. Bowsher, C., Chipman, S., Pozen, R., \& Ciesielski, J. (2012). Auditor independence and audit firm rotation: Responses to the PCAOB's concept release. The CPA Journal, 82(5), 6-12.

2. Chan, K., Farrell, B., \& Lee, P. (2008). Earnings management of firms reporting material internal control weaknesses under Section 404 of the Sarbanes-Oxley Act. Auditing: A Journal of Practice \& Theory, 27, 161-180.

3. Chan, K., Lee, P., \& Seow, G. (2008). Why did management and auditors fail to identify ineffective internal controls in their initial Section 404 reviews? Review of Accounting and Finance, 9, 338-354.

4. Daugherty, B., Dickins, D., Hatfield, R., \& Higgs, J. (2012). An examination of partner perceptions of partner rotation: Direct and indirect consequences to audit quality. Auditing: A Journal of Practice \& Theory, 31(1), 97-114.

5. General Accounting Office (GAO). (2003). Public accounting firms required study on

6. the potential effects of mandatory audit firm rotation. Washington, D.C.

7. Lim, C., \& Tan, H. (2010). Does auditor tenure improve audit quality? Moderating effects of industry specialization and fee dependence. Contemporary Accounting Research, 27, 923-957.

8. PCAOB, Release No. 2011-006: Concept Release on Auditor Independence and Audit Firm Rotation, August, 2011.

9. Ruiz-Barbadillo, E., Go'mez-Aguilar, N., \& Carrera, N. (2009). Does mandatory audit firm rotation enhance auditor independence? Evidence from Spain. Auditing: A Journal of Practice \& Theory, 28(1), 113-135.

10. Securities and Exchange Commission (SEC). (2003). Final rule: Management's reports on internal control over financial reporting and certification of disclosure in exchange act periodic reports. Release Nos. 338238. Washington, D.C.: SEC.

11. Tanyi, P., Raghunandan, K., \& Barua, A. (2010). Audit Report Lags after Voluntary and Involuntary Auditor Changes, Accounting Horizons, 24(4), 671-688.

12. Whalen, D., \& Cheffers, M. (2012). A restatement analysis of the Russell 1000 companies. Audit Analytics. 